\title{
By Design: How Departments Influence Graduate Student Agency in Career Advancement
}

\author{
KerryAnn O'Meara \\ Counseling, Higher Education and \\ Special Education, \\ University of Maryland, \\ College Park, MD, USA \\ komeara@umd.edu \\ Jennifer Eliason \\ Counseling, Higher Education and \\ Special Education, \\ University of Maryland, \\ College Park, MD, USA \\ jeliasonumd@gmail.com

Kelly Cowdery
Counseling, Higher Education and
Special Education,
University of Maryland,
College Park, MD, USA
kcowdery@umd.edu

Audrey Jaeger

Higher Education, NC State University, Charlotte, NC, USA

ajjaeger@ncsu.edu

Ashley Grantham

Higher Education, NC State University, Charlotte, NC, USA

\begin{abstract}
Material published as part of this publication, either on-line or in print, is copyrighted by the Informing Science Institute. Permission to make digital or paper copy of part or all of these works for personal or classroom use is granted without fee provided that the copies are not made or distributed for profit or commercial advantage AND that copies 1) bear this notice in full and 2) give the full citation on the first page. It is permissible to abstract these works so long as credit is given. To copy in all other cases or to republish or to post on a server or to redistribute to lists requires specific permission and payment of a fee. Contact Publisher@InformingScience.org to request redistribution permission.
\end{abstract}

This mixed methods study explored how departments enhanced graduate student agency in career advancement for doctoral students in science, technology, engineering and mathematics (STEM). Departments positively influenced graduate student agency by (1) encouraging and legitimizing multiple career paths, (2) providing structured opportunities for students to practice skills and experience different work environments, (3) providing resources (financial support and information), (4) facilitating networking, and (5) offering mentoring and guidance. Because agency in career advancement is important to students' motivation, completion, and career placement, departments should consider implementing concrete strategies to support graduate student agency.

Keywords: agency, doctoral students, STEM, career advancement, department influences, career paths, work environments, skills, resources, networking, mentoring, guidance 


\section{Introduction}

Darius, an engineering student, and Leslie, a biology student, arrived on campus on the same day to begin their doctoral programs. However, three years into their studies, they find themselves in very different places. Darius feels stuck in his ability to move forward in completing his degree and obtaining a position as an engineer, whereas Leslie feels confident she can complete within the time-table she has set for herself and obtain a position as a biologist. Darius is not seizing opportunities to gain important skills needed for his dissertation research and future career, whereas Leslie keeps finding new internships and summer opportunities. Leslie had important questions related to her comprehensive exam and went to her committee members for answers. Darius is afraid to seek out the advice of his advisor regarding the topic of his dissertation. Overall, Darius is concerned that the one career option he sees for himself, to become a faculty member, is not a good fit with his talents and interests. Yet, he does not know what else he will do if he ever completes his Ph.D. Leslie believes completing a good dissertation and landing her first job is going to be hard, but it is within her control.

There are a number of ways research on graduate education might explain Darius and Leslie's different experiences. Most often, doctoral student experiences are examined through the lens of socialization theory, which considers how students are accessing knowledge, skills, and orientations that influence key graduate student outcomes (Weidman, Twale, \& Stein, 2001). Darius and Leslie both have social identities at play in these scenarios that influence their experiences (Ferreira, 2003; Fries-Britt, Younger, \& Hall, 2010; Haley, Jaeger, \& Levin, 2013; Lindholm, 2004). In addition, Leslie may be better supported financially, which influences time to degree, retention, and degree completion (Golde, 1998; Lovitts, 2001).

Although each of these viewpoints is helpful in understanding Darius and Leslie's different experiences, we think an important perspective, the lens of agency, is missing. By agency we mean the perspectives graduate students assume, and the actions graduate students take to pursue goals that matter to them (Campbell \& O'Meara, 2013; O'Meara, 2013). Seen through the lens of agency, Leslie is exhibiting "agentic perspectives" and taking "agentic actions" to move forward in her career. Darius is assuming perspectives that make him feel boxed in, isolated, and without choices. He does not seem to be asking for help when needed or seeking new opportunities. There are, of course, many likely influences on these doctoral students' different levels of agency, which could be individual, organizational, and societal. Among potential influences, departments are particularly important. Given academic departments are where graduate students are admitted, take classes, complete dissertations, and search for jobs, it makes sense to consider departments as central forces that can enable or constrain graduate student agency (Frasier, 2013; Gardner, 2007, 2010; Golde, 2005).

The purpose of this paper is to examine the specific ways in which departments influence graduate student agency in career advancement. To deepen understanding of the kinds of agency departments might influence, we examine the agentic perspectives and actions exhibited by graduate students. Understanding graduate student agency and department influences are important for three reasons. First, assuming agency in advancing one's own academic and professional career is important for becoming a successful professional (Eteläpelto, Vahasantanen, Hokka, \& Paloniemi, 2013). Second, much research in human development shows assuming agency is associated with goal achievement, greater life satisfaction, and well-being (Alkire, 2005; Marshall, 2005; Sen, 1985). Third, agency in career advancement is particularly important for women and doctoral students of an underrepresented race and/or ethnicity (e.g. Asian American and Pacific Islander, Black, Latino/a, Native American, and Bi- or Multi-racial), as there are built-in constraints and biases that work against their success (Ampaw \& Jaeger, 2012; Cech, Rubineau, Silby \& Seron, 2011; Gonzalez, 2006). Although many individual and societal factors constrain 
and enable agency, studying the central organizational influence (department) on graduate students' sense of agency has the most implications for reform of graduate programs.

Understanding graduate student agency in career advancement is important in all fields, but especially in the academic disciplines of science, technology, engineering, and mathematics (STEM), because there is a compelling national interest in retaining and advancing more graduate students in science careers (National Science Foundation, 2004). In many STEM departments, there is a strong faculty preference for doctoral students to pursue academic positions (Gardner, 2007; Szelenyi, 2013) because most research universities reward faculty for placing doctoral students in prestigious academic positions at other higher education institutions (Gardner, 2010). However, unlike in areas such as the humanities, there is strong interest, and often more opportunity, for STEM students to pursue nonacademic positions. Completion rates for STEM doctoral students on average are about 59.1\% (Council of Graduate Schools, 2010). Regardless of whether they graduate into government, industry, or academic positions, STEM doctoral students will need agency to complete their doctoral degrees, and make choices about which careers to pursue. Previous research has demonstrated the critical role departments play in developing the aspirations, skill sets, knowledge, and overall talent of doctoral students (Golde, 2005). Yet little work has explored the role departments play in facilitating agency in career advancement for STEM doctoral students. Given the national interest in moving these students into academic careers, it is important to know how departments are facilitating agency in career advancement as part of the educational process. The research questions guiding this project were:

- To what extent do STEM doctoral students exhibit agentic perspectives or agentic actions in career advancement?

- How do departments enhance graduate student agency in career advancement?

\section{Theoretical Framework}

This work is framed by agency theory in the social sciences and research on the impact of department environments on graduate student outcomes. We utilize O'Meara, Campbell, and Terosky's (2011) definition of agency as a graduate student or other academic member assuming strategic perspectives, and/or taking strategic actions toward goals that matter to him/her. This conceptualization of agency builds from an extensive literature review of social science literature (for key works see Alkire, 2005; M. S. Archer, 2000, 2003; Emirbayer \& Mische, 1998; Eteläpelto et al., 2013; Ganz, 2010; Marshall, 2000, 2005; Neumann, Terosky, \& Schell, 2006; Sen, 1985).

Using this conceptualization, agency has two forms: perspective, or making meaning of situations and contexts in ways that advance personal goals; and the actions taken to pursue goals in a given situation (Campbell, 2012; O'Meara et al., 2011). Western cultures tend to think of agency as primarily actions (Welzel \& Inglehart, 2010) but thoughts have an important role to play in agency as well. Neumann and Pereira (2009) explained agentic perspectives as meaning-making, which "entails a reflexive purposefulness, a thoughtful directedness born of personal desire and valuing" (p. 139). M. S. Archer (2003) referred to this expression of agency as "reflexive deliberation of agents" (p. 135). Agentic perspectives are a form of self-talk, a set of perspectives or views taken when experiencing opportunities and constraints in pursuit of a goal. For example, a graduate student's department may discourage the pursuit of non-academic jobs. The student might take an agentic perspective by listening to advice about academic jobs, but not letting department norms dominate his/her sense of options. He/She decides internally to keep his/her options open. In this way, the student remains a strong "evaluator" of his/her situation, with his/her own priorities in mind, and this perspective helps him/her to achieve his/her career goals (M. S. Archer, 2000, 2003). 


\section{By Design}

Agentic action is discrete from, but often closely follows, and is related to, agentic perspective. In the same situation mentioned above, the graduate student might initiate contact with industry or foundation scientists to explore other career options, complete internships in both academic and non-academic labs to compare options, or simply read more on the job market in both fields. Agentic actions are strategic and are enacted with self-awareness of goals and contexts (L. Archer, 2008; M. S. Archer, 2000, 2003; Marshall, 2000, 2005; O’Meara et al., 2011). The nature of the agentic actions could be in line with the status quo, or in resistance to it (Ahearn, 2001; Marshall, 2005; O’Meara et al., 2011).

Agency should be considered "project specific" (Archer, 2003). Archer (2003) noted that agents (in this case, graduate students) internally construct their own projects (i.e., goals) and some notion of how to achieve them. Projects are developed within a specific circumstance or social context. In this study, we were interested in doctoral student agency in career advancement, a "project" which includes making progress toward degree completion, developing career goals, and making efforts to attain them. We wanted to understand both agentic perspectives and agentic actions in career advancement and department influences on them.

A common critique of agency theory is that it underestimates the impact of structure or habitus in shaping individual experiences (Bourdieu, 1986, 1990). Yet our concept of agency assumes that individuals are embedded in social contexts that shape the range of agency they may experience at any given time (Marshall, 2005). As numerous studies have demonstrated, a myriad of social identities, and the interactions between those identities and their academic departments will enable and constrain graduate student agency (Fries-Britt et al., 2010; Millett \& Nettles, 2006; Rhoades, Kiyama, McCormick, \& Quiroz, 2008). However, an individual's fate is not determined by his/her social context because individuals have free will and can "produce" their worlds (Elder, 1994; Lawton, 1989; Lerner \& Busch-Rossnagel, 1981).

Likewise, department policies, practices, and field norms will influence the range and degree of agency that doctoral students assume in pursuit of their goals and this agency can fluctuate based on a variety of factors (Council of Graduate Schools, 2010; Gardner, 2008; Golde, 1998). For example, a department that brings in alumni placed in federal government positions and encourages graduate students to learn about their career paths has engaged in a practice likely to encourage student agency in career advancement. Such events provide a sense of concrete options, and legitimize non-academic career choices. Yet Emirbayer and Mische (1998) pointed out that agency is also temporally constructed, meaning that as an agent interacts with his/her environment and responds, he/she does so in the present moment, but informed by the past and oriented toward the future. Thus, while meeting government scientists may have enhanced a student's sense of agency, if his/her faculty advisor discourages non-academic positions the next day, the graduate student's agency may decrease.

Although we are not aware of specific research on department influences on graduate student agency in career advancement, there is much literature on department influences on other graduate student outcomes that is relevant to this study. Most entering STEM doctoral students intend to complete their degrees and pursue academic careers; however, many drop out and/or change plans within the next 3-4 years (Golde \& Dore, 2001; Nerad, 2009). Researchers have found the following factors play important roles in graduate student degree completion and career choice: faculty mentoring, advisor-advisee relationship, and role-modeling (Austin, 2002; Fuhrmann, Halme, O'Sullivan, \& Lindstaedt, 2011; Lovitts, 2001; Mason, Goulden, \& Frasch, 2009; Millet \& Nettles, 2006; O'Meara, Knudsen, \& Jones, 2013; Paglis, Green, \& Bauret, 2006), a sense of fit between career goals and department expectations and values (Gardner, 2008, 2009, 2010; Haley et al., 2013; Lindholm, 2004; Rios, 2010), peer support and culture (Ali \& Kohun, 2006; Gardner, 2007; Gonzalez, 2006; Mwenda, 2010), department policies and programs (Fuhrmann et al., 2011; O'Meara et al., 2013), perceived compatibility of doctoral work and career with other 
life goals (Ferreira, 2003; Golde \& Dore, 2001; Mason et al., 2009; van Anders, 2004), and perception of acquired social capital and resources (Council of Graduate Schools, 2010; Millett \& Nettles, 2006). These same factors are likely to influence graduate student agency in career advancement (Eteläpelto et al., 2013; Szelenyi, 2013).

Perhaps one of the most important ways departments might influence agency is by enhancing student self-efficacy in research or teaching. Bandura (1989) defined self-efficacy as being "concerned with judgments of how well one can execute courses of action required to deal with prospective situations" (p. 122). Self-efficacy is extremely important for enhancing graduate student agency in career advancement because individuals who believe that they can do something are more likely to assume agency to do it than those who do not (Bandura, 1989).

Furthermore, the nature of the STEM discipline itself influences retention and career choice as each field and department has its own values, customs, and norms (Golde, 1998, 2005; Szelenyi, 2013). Requirements such as teamwork in labs, grant-writing, and order of authorship of papers as well as career options and typical career paths vary greatly among STEM fields and may influence graduate student agency. Program stage, institutional characteristics and norms, and career goals also influence student agency in career advancement. Students, who enter an academic program feeling very confident in their skills and abilities, may flounder and feel ill-prepared to conduct research on their own once entering the dissertation stage (Weidman et al., 2001). Also, researchers have shown institutions that are striving to move up in rankings put more pressure on students to complete their degrees swiftly and become faculty at research universities (Gardner, 2010). Finally, given the tendency for academic advisors to think of graduate education as preparation for the professoriate, those students who want to be faculty may feel more agency in pursuit of that goal than someone who wants to work in a national lab because the former student has more information about the position, encouragement, and role models (Gardner, 2010; Golde, 2005).

\section{Study Design}

The present study utilized a mixed methods design of concurrent triangulation (Creswell, 2003; Creswell \& Plano Clark, 2011; Johnson, Onwuegbuzie, \& Turner, 2007). In concurrent triangulation both quantitative and qualitative data are collected simultaneously, with the goal of confirming or substantiating findings within a single study. Creswell (2003) observed that in such studies, one can offset the weakness of one method with another method, priority can be given to either, and findings are integrated and interpreted together. We utilized quantitative (survey) data to understand the extent of graduate student agentic perspectives and actions but then emphasized qualitative data (in the form of interviews) to understand how departments enhanced graduate student agency in career advancement.

A mixed methods approach was warranted for several reasons. First, given that agency has only recently been used to frame graduate student experiences (see Rhoades et al., 2008; Szelenyi, 2013) and no research has operationalized graduate student agency in career advancement, we wanted to contextualize what we meant by agency in career advancement, and map the extent of it within a larger sample. A brief survey with items focused on agentic perspectives and actions accomplished that purpose. However, we also wanted to know what was happening between graduate students and their departments that enhanced agency. We wanted a richer set of concrete examples than a survey would provide and thus found interviews with individuals who had also taken the survey helpful to accomplish this goal.

We engaged in purposeful sampling based on contexts we know are likely to influence doctoral student experiences such as gender (Ferreira, 2003), race and ethnicity (Gonzalez, 2006), program stage (Ampaw \& Jaeger, 2012; Bowen \& Rudenstine, 1992), and STEM subfield or discipline 
(Golde, 2005). We chose to interview students after they had completed their comprehensive exams. Studies have shown many students change or amend their career goals during this period and can become discouraged; thus, it is a critical time for department support (Ampaw \& Jaeger, 2012). We distributed the survey to STEM doctoral students at two major research universities. Both universities, hereby referred to as University A and University B, are classified by the Carnegie Foundation (2010) as having very high research activity and have nationally ranked programs in the STEM disciplines.

We conducted an extensive review of social science theory on agency, with a particular focus on professional agency (Alkire, 2005; Bandura, 2000; Etelapelto, Vahasantanen, Hokka \& Paloniemi, 2013). Key components and elements of agency were identified through the literature and formed the basis for development of survey items. The construct of agentic perspectives was developed to include a sense of self efficacy, locus of control, awareness of choices, and empowerment to overcome obstacles; the construct of agentic actions was developed to encompass strategic choices and behaviors to accomplish meaningful goals. Our survey had 14 items. Six items measured agentic perspectives in career advancement, eight measured agentic actions. Each item had a five-point Likert scale, from 1 equaling "strongly disagree" to 5 equaling "strongly agree". These 14 items measuring graduate student agency served as the dependent variables. We pilot tested the survey with a small sample of graduate students and made minor modifications and sent it to graduate students using Qualtrics survey software. Among 2,062 STEM doctoral students surveyed, $884(42.9 \%)$ completed the survey. Demographics on survey respondents are provided in Table 1.

Table 1. Independent Variables, Survey

\begin{tabular}{|c|c|c|c|c|c|}
\hline & $\mathrm{N}$ & $\%$ & & $\mathrm{~N}$ & $\%$ \\
\hline Program Stage & 853 & & Discipline & 850 & \\
\hline Early/Mid Coursework & 220 & 25.79 & Bio Sciences & 156 & 18.35 \\
\hline Late Coursework & 124 & 14.54 & Engineering & 394 & 46.35 \\
\hline Proposal/Qualifying Exam & 218 & 25.56 & Chemistry & 83 & 9.76 \\
\hline Dissertation/Thesis & 291 & 34.11 & Computer Sciences & 64 & 7.53 \\
\hline & & & Physics & 87 & 10.24 \\
\hline & & & Earth Geological Sciences & 66 & 7.76 \\
\hline Career Goal & 854 & & Interview & 854 & \\
\hline Faculty, Research $U$ & 231 & 27.05 & Yes & 490 & 57.38 \\
\hline Faculty, Non-Research $U$ & 71 & 8.31 & No & 364 & 42.62 \\
\hline Government & 115 & 13.47 & Institution & 866 & \\
\hline Industry/Private Sector & 311 & 36.42 & University $A$ & 418 & 48.27 \\
\hline Postdoc & 39 & 4.57 & University $B$ & 448 & 51.73 \\
\hline Other & 87 & 10.19 & & & \\
\hline
\end{tabular}

From the completed surveys, we solicited interviews with students who represented a diverse mix of gender and race within STEM. We had 50\% women in the sample, 29 White students, 2 Native American Students, 8 Latino/Latina students, 5 Black students, 7 Biracial students, and 9 Asian American Students (see Table 2). We held the academic program stage constant by interviewing students in the post-comps phase of their work. This criterion sampling technique (Mertens, 2010, p. 322) to recruit, identify, and select participants yielded 61 interviews (31 from University A, 30 from University B). The interviews lasted between 35 and 90 minutes, with most interviews lasting 45-60 minutes. 
Table 2. Interviewee Demographics

\begin{tabular}{|c|c|c|c|c|c|}
\hline & $\mathrm{N}$ & $\%$ & & $\mathrm{~N}$ & $\%$ \\
\hline Race and Ethnicity & 60 & & Discipline & 60 & \\
\hline $\begin{array}{r}\text { Asian, Asian-American, } \\
\text { Pacific Islander }\end{array}$ & 9 & 15 & Biological Sciences & 13 & 22 \\
\hline Biracial or Multiracial & 7 & 12 & Engineering & 23 & 38 \\
\hline Black & 5 & 8 & Chemistry & 6 & 10 \\
\hline Latina/Latino & 8 & 13 & Computer Science & 5 & 8 \\
\hline Native American & 2 & 3 & Physics & 9 & 15 \\
\hline \multirow[t]{2}{*}{ White } & 29 & 48 & $\begin{array}{r}\text { Applied Mathematics, Sta- } \\
\text { tistics \& Scientific Compu- } \\
\text { tation }\end{array}$ & 2 & 3 \\
\hline & & & $\begin{array}{r}\text { Marine, Earth, and Atmos- } \\
\text { pheric Sciences }\end{array}$ & 2 & 3 \\
\hline Gender & 30 & & & & \\
\hline Female & 32 & 53 & & & \\
\hline Male & 28 & 47 & & & \\
\hline
\end{tabular}

The semi-structured interview format allowed the researchers to have a general guide for the interviews but gave participants the flexibility to guide the direction of the interview (Knox \& Burkard, 2009). The interview questions relevant to this study focused on aspects of the students' departmental environment that influenced how they felt, and what they were doing with regard to career advancement. Face-to-face interviews enabled us to observe social cues and nonverbal communication, and these elements provided deeper insights into the participants' graduate school experiences (Opdenakker, 2006). We audio-recorded and transcribed all interviews with participant permission.

The qualitative data analysis process was both concept and data driven (Kvale \& Brinkman, 2009). Concept-driven coding involves the use of pre-determined codes from the literature to guide analysis of the data, whereas data-driven coding allows key codes or themes to emerge from the findings, much as in grounded theory (Glaser \& Strauss, 1967). Here we were sensitized by our literature review to look for certain conditions within the department (e.g., good mentoring) that were likely to influence graduate student agency, but also allowed themes we had not seen before to emerge directly from the data.

Consistent with methodological norms of qualitative inquiry, data analysis included reading and rereading of interview transcripts to identify key emerging themes (Merriam, 1998; Miles \& Huberman, 1994). We read the transcripts multiple times and made notes in the margins until we had a strong grasp on each participant (Creswell, 2007). Employing a constant comparative method (Merriam, 1998), we analyzed each interview for department actions and conditions that seemed to influence graduate student agency in career advancement.

In the survey data analysis, negative items were reverse scored. Participants' willingness to participate in a follow-up qualitative interview was considered an additional independent variable to best understand potential differences and biases in our survey and interview samples.

Survey findings were evaluated using two-sample t-tests where the categorical independent variable allowed for only two options (e.g., institution, interview). Where categorical independent 
variables allowed for more than two options (e.g., discipline/department), we evaluated survey findings using two-way analysis of variance (ANOVA). When overall difference was discovered in the ANOVA analysis, a post-hoc Scheffé test was applied to determine the significant differences among the groups in each applicable independent variable.

Overall trustworthiness in the study was strengthened by collecting data from multiple sources including interviews with individuals from different backgrounds, department experiences, and survey data (Lincoln \& Guba, 2000). We engaged in member checking by sharing transcripts with participants and did not receive any disparate reports. All participants were provided anonymity. Internal validity was strengthened by authors analyzing the transcripts separately to develop themes and then joining to compare these conclusions. We analyzed transcripts through "thematic memoing" and then joint conceptualization of final themes (Rossman \& Rallis, 2003, p. 291-292).

There are several limitations to our research design. First and foremost, we were not able to directly connect the kinds and levels of graduate student agentic perspectives and agentic actions found in our qualitative and quantitative data. Nor were the data longitudinal, so we do not know if agentic perspectives and agentic actions lead to greater retention and career placement from this study. Second, in comparison to the broader sample of students who took our survey, students who offered to be interviewed had significantly higher mean averages on 6 of 14 agency items. For example, interview volunteers were statistically more likely to see multiple paths to be successful in achieving their career goals $(\mathrm{p}<.01)$ and were more likely to seize opportunities to advance career goals when they are presented $(p<.001)$. Thus, our interview participants were more agentic than the entire survey population. Interview participants might have been more interested in, and receptive to, efforts by departments to support them. Future research might target students for interviews who receive lower, average, and higher scores on agency measures to see if different interventions are more effective for different groups. Third, for space reasons we were not able to share findings related to department efforts that constrained agency in career advancement. Fourth, although we recognize that individual characteristics such as gender, race, marital/dependency status, nationality, sexual orientation, program stage, and career goals will also influence graduate student sense of agency, we did not analyze individual influences on graduate student agency in this study, but do so in another article. Such findings are covered in other studies but nonetheless factor in the ways in which students interacted with their departments.

This study makes an important contribution to research on graduate education by (a) applying the theoretical lens of agency to understanding graduate student experiences, (b) employing a mixed method approach to the study of STEM graduate student agency in career advancement, and (c) examining the specific ways in which departments enhance graduate student agency in career advancement. At the end of this article we identify implications of our findings for departments and posit areas for future research.

\section{Findings}

We organized our findings in two sections. First, we present the survey results regarding the nature and extent of STEM graduate student agentic actions and perspectives and whether or not they varied by department. Second, we describe five ways departments enhanced graduate student agency in career advancement.

\section{Graduate Student Agency in Career Advancement}

STEM graduate students reported a good degree of both agentic actions (means between 3.83 and 4.14 of survey items with a 5-point Likert scale) and agentic perspectives (means between 3.35 and 4.17) with on average higher means for agentic actions than perspectives (Tables 3 and 4). 
Further, standard deviations were lower on questions about agentic actions than about agentic perspectives, revealing less variation in doctoral student responses, which suggests that STEM doctoral student participants report a high degree of confidence in their ability to take strategic actions to advance their career goals. Yet, the STEM doctoral students' internal perspectives and monologues about their ability to achieve their professional goals reflected a larger degree of variance.

Table 3. Agentic Actions

\begin{tabular}{|c|c|c|c|}
\hline & $\mathrm{N}$ & Mean & $\mathrm{SD}$ \\
\hline I have been strategic in achieving my career goals. & 868 & 3.83 & 0.84 \\
\hline $\begin{array}{l}\text { I have intentionally made choices to focus my career goals } \\
\text { in ways that are personally meaningful to me. }\end{array}$ & 868 & 4.14 & 0.77 \\
\hline $\begin{array}{l}\text { I seize opportunities when they are presented to me to ad- } \\
\text { vance my career goals. }\end{array}$ & 867 & 4.13 & 0.76 \\
\hline $\begin{array}{l}\text { If I lack something (e.g. a skill or specific knowledge) that } \\
\text { I need to obtain my career goals, I take steps to obtain it. }\end{array}$ & 865 & 4.12 & 0.68 \\
\hline $\begin{array}{l}\text { When I face a setback, I take strategic steps to overcome } \\
\text { the barrier to move ahead. }\end{array}$ & 864 & 4.01 & 0.62 \\
\hline I ask for help when I need it. & 865 & 3.87 & 0.89 \\
\hline
\end{tabular}

Note: Means and standard deviation (SD) were calculated for respondent's answers on a 5-point likert scale with $1=$ Strongly Disagree and 5=Strongly Agree.

Table 4. Agentic Perspectives

\begin{tabular}{|c|c|c|c|}
\hline & $\mathrm{N}$ & Mean & SD \\
\hline $\begin{array}{l}\text { I feel stuck in my ability to advance toward my career } \\
\text { goals. }^{+}\end{array}$ & 864 & 3.35 & 0.99 \\
\hline $\begin{array}{l}\text { In general, I feel that I have little control over whether I } \\
\text { advance my career goals. }\end{array}$ & 867 & 3.68 & 1.02 \\
\hline $\begin{array}{l}\text { My advisor (rather than I) controls whether I will achieve } \\
\text { my career goals. }\end{array}$ & 868 & 3.66 & 1.03 \\
\hline $\begin{array}{l}\text { I know how to conduct research to achieve my career } \\
\text { goals. }\end{array}$ & 867 & 3.79 & 0.79 \\
\hline $\begin{array}{l}\text { When I face a setback, I view it as a temporary roadblock } \\
\text { that I can overcome. }\end{array}$ & 865 & 4.03 & 0.69 \\
\hline $\begin{array}{l}\text { I can acquire all of the knowledge and skills that I need to } \\
\text { be successful in my career goals as long as I work hard. }\end{array}$ & 866 & 4.04 & 0.92 \\
\hline I view critical feedback on my work as a way to grow. & 864 & 4.17 & 0.92 \\
\hline $\begin{array}{l}\text { Rather than seeing one path, I see there are multiple paths } \\
\text { to be successful in achieving my career goals. }\end{array}$ & 864 & 4.12 & 0.79 \\
\hline
\end{tabular}

${ }^{+}$Reverse coded survey questions

Note: Means and standard deviation (SD) were calculated for respondent's answers on a 5-point likert scale with $1=$ Strongly Disagree and 5=Strongly Agree.

When we examined graduate students' agentic actions in career advancement, there were some differences by discipline as doctoral students in physics $[F(5,844)=5.00, p<.01]$ believed that they were less strategic in achieving their career goals than their counterparts in biological sciences, engineering, and chemistry (Table 5). When we examined graduate students' agentic per- 
spectives toward career advancement, physics students reported lower levels of agentic perspectives in their ability to conduct research to achieve career goals $[F(5,843)=3.71, p<.01]$ than biological science students (Table 6).

Table 5. Analysis of Variance for

"have been strategic in achieving my career goals" (n1), by Discipline

\begin{tabular}{|c|c|c|c|c|c|c|c|}
\hline \multicolumn{2}{|l|}{ Source } & SS & df & MS & $\mathrm{F}$ & $\mathrm{P}$ & \\
\hline \multicolumn{2}{|c|}{ Between } & 17.36 & 5 & 3.47 & 5.00 & .001 & \\
\hline \multicolumn{2}{|l|}{ Within } & 585.56 & 844 & 0.69 & & & \\
\hline \multicolumn{2}{|l|}{ Total } & 602.92 & 849 & & & & \\
\hline \multicolumn{6}{|c|}{ Scheffe Post-hoc Comparison $(\mathrm{p}<.05$ or below displayed) } & \multicolumn{2}{|c|}{$95 \%$ Confidence Interval } \\
\hline $\mathrm{I}(\mathrm{n} 3)$ & $J(n 3)$ & Coefficient & & Std. Error & Significance & Lower Bound & Upper Bound \\
\hline \multirow[t]{3}{*}{ Physics } & Biological Sci & $-.504421^{* * *}$ & & .0666888 & 0.001 & -.6353165 & -.3735255 \\
\hline & Chemistry & $-.352267 *$ & & .1131652 & 0.027 & -.57438515 & 42091225 \\
\hline & Engineering & $-481097 *$ & & .0787927 & 0.015 &.- .6357497 & .-.3266444 \\
\hline
\end{tabular}

Table 6. Analysis of Variance for

"I know how to conduct research to achieve my career goals" (n8), by Discipline

\begin{tabular}{|c|c|c|c|c|c|c|c|}
\hline Source & & SS & df & MS & $\mathrm{F}$ & \multicolumn{2}{|l|}{$\mathrm{P}$} \\
\hline Between & & 11.43 & 5 & 2.29 & 3.71 & \multicolumn{2}{|l|}{.003} \\
\hline Within & & 519.83 & 843 & 0.62 & & & \\
\hline Total & & 531.26 & 848 & & & & \\
\hline \multicolumn{6}{|c|}{ Scheffe Post-hoc Comparison $(\mathrm{p}<.05$ or below displayed) } & \multicolumn{2}{|c|}{$95 \%$ Confidence Interval } \\
\hline $\mathrm{I}(\mathrm{n} 3)$ & $J(n 3)$ & Coeffici & & Std. Error & Significance & Lower Bound & Upper Bound \\
\hline Physics & Biological Sci & -.41733 & & .1050743 & 0.008 & -.6235677 & -.2110919 \\
\hline
\end{tabular}

\section{Department Influences on Graduate Student Agency in Career Advancement}

We found five ways in which departments, via actors and the structures and cultures they enacted, enabled graduate student agency in career advancement: (1) encouraging and legitimizing multiple career paths, (2) providing structured opportunities for students to practice skills and experience different work environments, (3) providing resources (financial support and information), (4) facilitating networking, and (5) offering mentoring and guidance. To underscore this point, when we say "departments enabled," we refer to the actions of specific actors (e.g., department chair, faculty, students), as well as the structures (e.g., requirements and resources), and cultural norms (e.g., expectations) those actors put in place and/or perpetuated to support graduate student agency in career advancement. Many of the specific strategies departments enacted served in more than one way to encourage agency in pursuit of career goals.

\section{Encouraging and legitimizing multiple career paths}

Previous research suggests that a key element of agency is feeling like you have choices and some freedom in achieving goals that matter to you (Alkire, 2005; O'Meara et al., 2011). Those in power can assert dominance by persuading individuals via an "institutional script" that there is only one way to do something (Powell \& Colyvas, 2008). The norm at most research universities is for faculty to support their doctoral students in pursuing faculty appointments at research uni- 
versities (Gardner, 2009, 2010). Such a singular focus on academic appointments could feel limiting and discouraging to students who do not feel they fit in academe. In our study, we found departments supported graduate student agency by encouraging and legitimizing multiple career pathways.

There were three ways in which departments encouraged and legitimized multiple career paths. First, department chairs, program faculty, as well as department graduate student associations hosted external speakers on a regular basis to discuss non-academic careers in industry, government, policy-making, and K-12 education. Students often had an opportunity to go to lunch or dinner with speakers (sometimes alumni or professional colleagues of faculty) and ask them questions regarding the content of their work, work-life environment, salary, and benefits. Such opportunities were often without their faculty, which allowed students more freedom, in their opinion, to ask questions that compared one career choice (such as academia) to another (such as industry). Ron, an astronomy student explained:

Yes, so I wouldn't say there's an emphasis on one particular track. One of the things my department has been very good about is in something called "the career path seminar." So they have established a seminar every week that is specifically focused on exposing graduate students who are on different career paths. So they have people coming in from let's say [local area], or from industry that did their Ph.D. in [field name] and now have gone into different fields. So there's always the emphasis on the most obvious track you know, go for post-doc, go for an academic position. But we all know that there aren't enough positions for all you know Ph.Ds. that are graduating. So you know this career path seminar has been really helpful in kind of exposing you to what is out there in terms of teaching, government administration, industry positions, programming, so I would say we've been fairly well exposed to a whole variety of things. There isn't, I wouldn't say there was an emphasis on pursuing a particular career path.

Many students raved about these seminars using words such as "valuable," "beneficial," and "enlightening" to describe them. Ron explained why they were important to him and others:

I think that has been pretty valuable for a lot of us, in also realizing if you don't get an academic position that's not the end of the world. There are a lot of other things happening. ... So I think part of what graduate students need to see is that there are other options and to help them figure out what options they want.

Students who attended these seminars appreciated their faculty acknowledging that the market was not good for tenure-track positions right now and that there were many other "legitimate" options. Several students noted they had made contacts for internships, summer jobs, and other good career connections from seminars. Joel, an engineering student, framed the seminars as a concrete set of "resources from the department itself."

Students in departments where there was openness to different careers and research agendas felt grateful, and noted they believed their department support was unique. Participants said that students they knew in other departments where faculty did not provide concrete examples and approval of multiple career paths felt "boxed in," discouraged, and limited. Kimberly, an astronomy student who had decided to go into K-12 teaching, said:

I think that's just one of the most valuable things about our department, 'cause a lot of peer schools don't provide that support for their students. The comfort level I had after I told them [about career choice], it made it much easier and they were very, very encouraging and supportive. You know the letters they wrote me, you know, got me in the door for my interviews. I'm not going to say they got me the job because I do work in the interviews, but you know they got me in the door. It's just a very collegial atmosphere. 
Everyone really looks out for each other and they acknowledge you know maybe it's not best for them if their students go teach high school, but if it's best for the student, that's what's important.

It is notable that Kimberly describes her agency in interaction with her department's support. They got her in the door but she had to do well for the opportunity to work out.

A second way that departments supported multiple career pathways was through very direct conversations and career encouragement between faculty advisors and students. Students acknowledged that faculty had a built-in bias toward academia but were also open, encouraging, and supportive of non-academic positions. For example, Orlando, a biochemistry student, said:

At first my advisor was skeptical because it's very well-known that professors want to make more professors, right, so my professor of course wanted me to become one at first. He would always tell me and a lot of the other students in our group, oh you're a great teacher you should be a research professor just like me. They want to do that, it's that relationship, that father-son kind of relationship that a dad wants his son to be the same, you know, when he grows up. But after a while, after telling him my reasons, my rationale for drifting away from academia, he agreed. He saw some of the faults of academia and some of the benefits and some pros and cons for industry, and I think he's been supportive about it.

Likewise, Bernard, a biology student, observed that he valued his advisor's openness to careers outside academe and that the advisor never "pushed [him] in one way or another." Bernard felt that his group of advisors had deeply invested in him as a person. Not going into academe was in some ways a "slap in the face to anyone involved in your $\mathrm{PhD}$ program." Therefore, it was very meaningful to Bernard that his advisors had "told [him and other students] everything [they] could do" with the doctoral degree.

A third way departments encouraged multiple pathways was as a by-product of the nature of some more applied subfields, which meant faculty had as many contacts outside academe as inside academe. Donna, a physics student, observed:

In [many] STEM [programs] you have a very developmental type of research where you build more theories, whereas we do more implementations. So we have more implementation .... working with industry. So we try to find the best way to get things into the market and things like that. So that's from the very beginning, in my graduate studies. So I was more exposed to that area ... That's probably why I wanted to go into industry as well.

Likewise, Bella, a biology student, explained that in her field one could focus on basic or applied research. Those doing applied research tended to go into industry; those doing more basic research went into academia. Bella appreciated being able to make the choice between basic or applied research and that faculty would help her with contacts and funding either way.

\section{Providing structured opportunities for students to practice skills and experience different work environments}

Departments supported graduate student agency in career advancement by providing concrete opportunities for students to learn and develop knowledge and skills, gain self-efficacy, and increase confidence and motivation in the work they would be doing in their future careers. Students who were able to role play and rehearse their future career roles felt more confident as legitimate members of their desired professions and were able to discover whether or not they enjoyed these aspects of potential future positions. 
For example, many students engaged in teaching as a teaching assistant or instructor for their department though the quality of teaching experiences varied between surface level and intense experiences. In the best experiences, students learned that they loved teaching and wanted to become teachers. Renee, a biology student whose graduate school provided the opportunity to earn a certificate in teaching, said:

In our department, we're required to TA one class per master's and two for $\mathrm{PhD}$. And that's been very helpful. Some classes are more beneficial than others. There are some classes where the TA just kind of grades and gives like a one-class presentation. But I had one that was just really good. Because we actually taught the lab. Me and one other student - we alternated teaching the lab every week. So I actually got hands-on experience of teaching labs ... I never had thought that I might want to be a teacher before that, actually.

For some students, their teaching experience changed their career goals. Kimberly, an astronomy student, explained:

So when I entered grad school I thought maybe I'd be a professor. I was kind of thinking more along those lines, but as I went through grad school, I realized that the most fun I had was when I was teaching, when I was giving talks either to a scientific audience or a public audience and that the research didn't fulfill me as much as the teaching did. So I thought high school might be a good venue. I taught the intro classes in astronomy. I really enjoy teaching people who have no background, or very little background in a subject and getting them to understand things for the first time and seeing that spark in their eyes.

While Kimberly had decided through her teaching experiences that she wanted to work in high school teaching, Bernard, a biology student, had the chance to teach both undergraduate and graduate students and decided the opposite. Bernard determined he fit better with graduate students and doing more research. He enjoyed working with more advanced students in a smaller class setting while working in a summer internship at federally funded labs. Thus, he knew he wanted a more research-oriented appointment post-graduation.

Students also mentioned opportunities created by departments to present research findings and interact with students and future colleagues. Nola, a chemistry student, observed:

We try to team up with other departments that have similar research foci that can overlap. And we do departmental seminar days where I get to present my research or I get to make a poster and learn to communicate on a [higher level].

Nola felt this research experience enhanced her confidence as a professional scientist. Lamar, a computer science student, also found that it was the act of presenting his work that reinforced his career goals and increased his agency in making them real. Lamar said:

Yes it [presenting his research] reminded me of what I like about my own research, because I like my own research. I just sometimes forget that I like it, and I think that's what all grad students do. And so, having these concrete events, physical things, social events, of interacting with other people in a way that you have to sell your own research in a way that sells it to yourself at the same time ... I come back from conferences feeling really gung ho.

Victoria, an engineering student, discussed how her department created practical training in grantwriting and professionalism:

And also there's a number of programs that I know that I've been involved with and some of my peers have been involved with to help sort of train future faculty members on research grant-writing. Our department requires very specific like proposal grant-writing, a 
class -- how to be a, you know, carry yourself professionally. That's helped shape the academic desire too.

Donna, a physics student, carefully pondered a priori versus department influences on her interest in becoming an academic. Donna said:

[T] here are things that influence your career decision but I think there are also things that you're doing to prepare for the career decision that you think you'll make. I think those two things are very intertwined and interrelated so some of the things that I've done I think of now as things that I did because I wanted to find myself in this career trajectory as opposed to things that changed my career trajectory. I mean if that makes sense? But I guess they are still sort of influential in the sense that they either affirm or show me missing pieces. So I think that some of the biggest things that I've done is just to do good research and I think that as a graduate student there's lots of opportunities to excel as a researcher especially in a place like [name of institution] where I'm in a large and wellfunded department with a lot of opportunities for good research and a lot of opportunities to interact with people who are at the top of my field.

Donna noted she received feedback from her department that was affirmative, while engaging in research in a department where she found ample opportunities to practice her craft. In some ways her department acted as a mirror, in others as a guide. Yet, Donna felt her career goals were supported while she remained an active agent in making her own career happen.

Departments also facilitated graduate student agency in career goals by encouraging internships where students not only practiced certain skills but were able to see how the work environment "fit" their personality and interests. In many cases these internships helped students make comparisons between academic work and industry or government work, and they found they fit better outside academe. For example, Tess, an engineering student, said:

The internship I had in industry with chemical engineering didn't really mesh, but one internship I had was in microbiology and I was over the moon about. That is why I pursed environmental engineering because it was a nice marriage of two fields I enjoy.

Tess reflected on how her internship allowed her to consider different work environments:

With my attitude and personality I think I am more suited for academia, but not suited for it long term. I would rather work for myself in consulting and use my skills to solve a broad array of problems.

Padma, an engineering student, explained how her internships helped in her discernment and her confidence about the right work environment for her career:

I've always wanted to be more hands-on with my research, and both my parents are faculty so I've always been interested in research, but my opinions about becoming a university faculty have changed based on my perception of the system ... I've done internships at both national labs and industrial labs, and I much prefer those atmospheres because there's a sense of team spirit and a better sense of sharing and less territorial sort of behavior in those sort of settings. That's definitely what has shaped my ambitions. Right now I would like to work in a more, sort of, friendly atmosphere.

Although some would read Padma's story and regret the fact that she found the academic life "less friendly" than national labs, the important point is that her department helped her by encouraging internships where she could test out work environments beyond academe, and determine how her career goals might be achieved there. 


\section{Providing resources (financial support and information)}

Graduate students in our study also linked the sense of agency they felt in achieving their career goals to tangible resources provided by their department. The connection between resources and agency is not surprising given that previous studies have revealed the value of professional development resources to faculty career advancement (Campbell \& O'Meara, 2013). For example, Frasier (2013) found that students who held TA or RA positions were less likely to have extended time to degree. Similarly, resources supporting graduate student agency in this study came in the form of RA and TA positions to support them financially as well as travel funds to attend research conferences, assistance with finding funding to support research projects, and ready information regarding jobs, internships, and related professional associations. For example, Hubert, a physics student, said:

The Physics Department has been fantastic for me. That fall semester they gave me a teaching assistantship, which they were under no obligation to do which allowed me to continue my research and work as a fulltime TA which is where I got some teaching experience in labs.

Students noted that one of the more valuable resources departments provided was information. Christian, a chemistry student, observed: "My undergrad and [name of institution] both do a pretty good job of giving professional development skills and opportunities in the form of certain databases online - you can look for public and private sector jobs." Nola, observed: "I think that within my department they're just really good at firing off anything that comes along, even if it's not in the state. They'll be like, 'Oh, there's funding for this, too.' And so they're pretty good at doing that." Thus, resources enhanced agency in career advancement by providing funding that allowed graduate students to focus more on their studies or by adding to student perception of their own social capital (via information and connections).

\section{Facilitating networking}

A fourth way in which departments in this study influenced graduate student agency in career advancement was by creating and facilitating opportunities for students to network with others regarding current and future career-related opportunities. Previous research found that strong external professional networks in one's field positively influence faculty agency behavior and sense of productivity (O'Meara \& Niehaus, 2013). Likewise, in this study networking was important to facilitating graduate student agency in career advancement. Ron, an astronomy student, noted opportunities for networking with outside speakers that his department brought in as well as networking between faculty and students at coffee hours held every day in the lobby. Another particularly impactful way that one department mediated and facilitated networking was research interaction teams. Ray, an applied mathematics student, explained:

That is constantly happening I feel - by design, I think, in my program. One really great opportunity we have are these "research interaction teams" are what they're called. There are graduate students, maybe in some cases advanced undergraduates, but it's a group of professors, graduate students, and depending on the topic, people from outside the university. So that's a constant influx of networking, I guess.

Ray went on to directly link his experiences in these networking events to his career goals:

I have to say that before I started these [seminars] sometime in my second year, I was pretty set on trying to pursue the academic route. So it has significantly influenced my thought process.

In terms of off-campus experiences, students mentioned internships, supported with credits toward degree by the department, and encouragement and support to attend disciplinary confer- 
ences. Donna, a physics graduate student, attended conferences where her faculty introduced her to other faculty at the top of their field. Such interactions increased Donna's self-confidence that she belonged in the research world and could hold her own in it.

In many cases department faculty called upon their networks within industry and academic circles to help students network in areas where they might start careers. Lamar explained:

My advisor is pretty well connected. I've had the chance to go to several workshops and meetings with the [department] that I probably would not have had under any other circumstances, and so that has led to a situation where I know a lot of people in my industry. I'm not sure if I'm interested in doing government work, but I feel very certain that I could secure a position if I wanted to. So, I feel like at least my advisor's network here has done very well for making sure that I have those opportunities if I want them.

Thus, departments exposed students like Lamar and others to professional networks where they could see themselves succeeding, therefore facilitating graduate student agency.

Faculty were not the only actors facilitating such networking inside departments. Many students mentioned women in science associations embedded in and supported by departments that held networking events. For example, Theresa, a biology student, noted her women in science group:

... teaches you how to network and connect you with other women who are in industry in the area. There's a lot of like small biotech companies around so it's been very helpful. I know a lot of people in their 5th year 6th year are going to those to try to meet people and get an in and find a job so that's been pretty nice.

Thus student organizations supported by department funds also played an important role in facilitating networking.

\section{Offering mentoring and guidance}

As noted earlier, research has shown the advisor-advisee relationship is critical to doctoral completion, satisfaction, and career choice (Girves \& Wemmerus, 1988; Golde, 2005; Mwenda, 2010; O'Meara et al., 2013). Departments scaffolded graduate student agency by providing supportive and accessible advisors who listened, helped students discern what they wanted, and provided strategic advice. Self-awareness has been found in previous studies to be an important influence on agentic perspectives and behaviors (Campbell \& O'Meara, 2013; O'Meara et al., 2011). This is because we need to know what we want in order to assume agency to pursue it. We found in our study that faculty played an especially important role in student self-awareness of goals and discernment. Many graduate students mentioned faculty helping them process career plans. Students observed that their current career goals sort of "came up" or evolved through discussions with their advisor or through contacts he or she made for them. For example, Wilmer, a physics student, said:

Yeah, in fact when I have, we can talk about my career issues, when I had my last 'what am I going to do' moment I just walked into my old advisor's office, kind of just sat down and said, 'What am I going to do with my life?' We chatted for a while, she gave good advice.

Wilmer left this faculty member's office with a more agentic perspective about his career possibilities and prospects. He felt more confident because he had talked the issues out with her. Victoria, an engineering student, observed that the good communication and supportive environment among her program faculty had "shaped the academic desire too."

Bella, a biology student, explained that the more exposure she had to program faculty, the more confident she felt about how she might fit into the faculty role. Bella said: 
I agreed to help coordinate the setup and cleanup after colloquium lunches and so I was interacting with more professors. I feel that I was getting better information about how professors budget their administrative duties. And I was kind of like "you know what? I could do this." And my advisor too was helping me prepare my proposal that I would give for my qualifying exam. And you have to talk a bit about what your future goals are and he [said] you're going to put something in there about academia right, and I was just like, yeah, I guess I am.

Bella felt more confident not only in pursuing the faculty role but in saying she wanted to become a faculty member once her advisor acknowledged he saw this as a path for her. His affirmation and recognition made her career aspirations more authentic and facilitated Bella stepping forward into the possibility of becoming a faculty member.

Faculty also supported student career goals in industry. Karrie, an engineering student, mentioned learning about a grant that would provide her an opportunity to start a new business. When asked how this started, she said:

It sort of came up through my advisor. So I have my main $\mathrm{PhD}$ advisor and then I also have a few people that we collaborate with ... So they were also the ones that sort of brought it up [entrepreneurial grant] and said maybe we should do this ... So after that we sort of thought more about it.

This example integrates many of the others above, as the faculty member, a representative of the engineering department, enhanced Karrie's agency in career advancement by having a discussion to discern her career goals. The advisor provided information about potential resources and encouragement so that Karrie might herself seize the opportunity to advance.

\section{Discussion and Implications}

This study makes a new contribution to the graduate student literature by examining how departments influence graduate student agency in career advancement. Previous research has examined how department characteristics such as resources, gender composition of the faculty, and department prestige influence graduate student outcomes, such as doctoral student satisfaction and completion (Ampaw \& Jaeger, 2012; Bowen \& Rudenstine, 1992; Council of Graduate Schools, 2010; Frasier, 2013; Gardner, 2007; Golde, 2005). However, our study examined STEM graduate student agency in career advancement, and the very specific ways departments influenced that agency. These findings have practical implications for graduate program directors, department chairs, graduate faculty and graduate students. Faced with significant financial constraints such as a decrease in federal and foundation funding for research, it is easy to see how many department chairs and faculties might want to do more to support graduate students in career advancement, but wonder what would make a tangible difference, especially without a significant influx of new resources.

Our findings suggest departments can be extremely influential in enhancing graduate student agency in career advancement without a significant influx of new resources. As the primary place where graduate students learn, grow, and strive to succeed, departments in our study were uniquely positioned to provide structured opportunities for students to try out different career options, discern the best choices for them, make connections within professional fields, legitimize student career choices, and encourage students to take agentic actions toward their own career advancement.

Departments enhanced graduate student agency in career advancement by providing opportunities for students to practice work roles in different careers, try out and become comfortable in different work environments, and see which environment best fit their talents and interests. Some de- 


\section{By Design}

partments required and others strongly encouraged internships, teaching experiences, and presenting at research conferences. It has been noted before that self-efficacy is a critical influence on agency (Bandura, 1989). Clearly these structured opportunities increased student self-efficacy in skills needed for specific careers. Similarly, Cech et al. (2011) found that professional role confidence, or the confidence a student has to successfully fulfill roles, competencies, and identity features of his/her desired profession predicts attrition from undergraduate engineering programs. In a similar way these structured opportunities further developed graduate students as independent scholars, a widely recognized part of doctoral student socialization (Gardner, 2008; Lovitts, 2001). Likewise, the students in this study who participated in these "dry-runs" as future faculty, industry scientists, or federal government scientists were able to explore whether they fit the identity characteristics of those they worked beside.

Departments also enhanced graduate student agency in career advancement by presenting, affirming, and legitimizing multiple career options. Students in this study observed faculty preferences for graduate students to pursue academic appointments as has been found in previous studies of STEM fields (Szelenyi, 2013). However, graduate students also noted how grateful they were that their department faculty had intentionally legitimized industry, government, policy, and nonresearch related education positions. Research universities are highly value-laden, prestigeoriented environments (Gardner, 2010; Szelenyi, 2013) and the fact that student advisors and peers recognized non-academic appointments as legitimate, desirable options gave students a sense of permission to view all options. This is especially important in STEM areas where constraints related to federal funding for research may make university positions less desirable. Alternatively, it is easy to see how constraining it would have been if department resources, advising and support only focused on one narrative or set of options for graduate students after graduation, as has been found in related studies (Gardner, 2010; Rhoades et al., 2008).

Department financial support also influenced agency in career advancement. However, smaller resources mattered to agency in career advancement as much as larger efforts like continuous funding. It might be considered a small thing for the department to pay for lunches and dinners between students and speakers, but it was not small to the graduate students in our study. They felt that departments paying for these meals signaled recognition for alternative career tracks. Many studies show financial support in the way of teaching assistantships, research assistantships, fellowships, and other financial awards impact time to degree and persistence (Council of Graduate Schools, 2010; Kim \& Otts, 2010; Frasier, 2013). Indeed, such support was important to graduate student agency in our study as well. However, we think it is important to note that even strategic use of small, scarce resources can make an important, symbolic, and tangible difference in supporting graduate student agency in career advancement as occurred with speaker dinners and lunches.

Departments also enhanced graduate student agency by facilitating strategic networking for their graduate students. Whether internal or external to the university, this networking added to students' perception of their own social capital. For example, departments scaffolded student agency by getting students inside meaningful conversations about research that mattered to them. Students then acted as agents by making valuable contributions to these conversations with new colleagues. Each professional connection the department facilitated made students feel more like insiders in the profession. Much research shows the power of social networks and professional relationships to build social capital (Nahapiet \& Ghoshal, 1998), increase an individual's "pull" in a field (Laird, 2006), and promote advancement (Christakis \& Fowler, 2009) and performance (Brandes, Dharwadkar, \& Wheatley, 2004). Students' perception of increased social capital in turn added to students' sense of confidence as a professional in a field of study, and sense of agency in career advancement. 
Finally, departments supported graduate student agency by having individual advisors as well as other faculty in the department listen to students, help them discern career interests, determine a fit between their talents and interests and career plans, and provide encouragement. Marshall (2005) described the process of agency as an intentional "structuring of choices" and actions (p. 11). Graduate students in this study felt that the advice their faculty gave them was extremely helpful, whether they were deciding to go into academic or non-academic appointments, in determining which directions they wanted to go, and what they needed to get there. Our findings related to the faculty role of listening, helping students become self-aware of goals, and discern next steps, is consistent with Jairam and Kahl's (2012) finding that the amount and quality of subject matter advice faculty provide is critical to student time to degree and the findings of O'Meara et al. (2013) on the role of emotional competencies in effective graduate advising. Equally important as good listening and awareness of students' interests was the sense of affirmation graduate students sought and received from faculty. For example, one student recalled vividly the moment her advisor had encouraged her to write down her plans to be a faculty member. This student had intentionally sought out the chance to get closer to faculty (an agentic action). Regardless, she noted how important it was to her that her advisor saw her in a faculty role before she committed to it.

This mixed methods research study was one of the first to explicitly consider agency in career advancement among STEM graduate students, and leaves much room for further research. First and foremost, we would like to see if graduate student agency in career advancement at certain key transition points (such as from comprehensive exams to early dissertation writing) predicts graduate student completion and time to degree. Second, for space reasons, the focus of this study was on the department factors that enabled graduate student agency. Further research should be done to understand department factors that constrain such agency. As noted earlier, we did not interview students by extent of agency found in survey responses. Subsequent studies might examine the kinds of department efforts most likely to enhance agency for students with the least expressed agency in career advancement, and at greatest risk of not completing. Such studies might also consider department efforts that are most impactful for enhancing the agency of underrepresented minorities in STEM disciplines.

In conclusion, as a key component of human development, agency is a critical resource needed to be successful in highly autonomous, professional positions (Ackerman, Zuroff \& Moskowitz, 2000; Archer, 2000; Elder, 1994; Emirbayer \& Mische, 1998; Lawrence, 2008). Agency in career advancement is important to graduate student motivation, completion, and career placement. Encouraging departments to consider the ways in which they support graduate student agency in career advancement does not diminish the role graduate students themselves play as agents who need to plan, navigate, and negotiate their own careers (O'Meara, 2013). However, as many have observed, the power of organizational environments to shape the range of choices and freedom of individuals within them is immense (Bourdieu, 1990; Eteläpelto et al., 2013; Giddens, 1979; Szelenyi, 2013). Thus it is important for departments, and the department chairs, faculty, students, and administrators within them, to take responsibility for the kind of environment they are creating for graduate students to assume agency.

\section{References}

Ackerman, S., Zuroff, D. C., \& Moskowitz, D. S. (2000). Generativity in midlife and young adults: Links to agency, communion, and subjective well-being. International Journal of Aging and Human Development, 50(1), 17-41.

Ahearn, L. M. (2001). Language and agency. Annual Review of Anthropology, 30, 109-137.

Ali, A., \& Kohun, F. (2006). Dealing with isolation feelings in IS doctoral programs. International Journal of Doctoral Studies, 1, 21-33. 
Alkire, S. (2005). Subjective quantitative studies of human agency. Social Indicators Research, 74(1), $217-$ 260.

Ampaw, F. D., \& Jaeger, A. J. (2012). Completing the three stages of doctoral education: An event history analysis. Research in Higher Education, 53(6), 640-660.

Archer, L. (2008). The new neoliberal subjects? Young/er academics' constructions of professional identity. Journal of Educational Policy, 23(3), 265-285.

Archer, M. S. (2000). Being human: The problem of agency. New York, NY: Cambridge University Press.

Archer, M. S. (2003). Structure, agency and the internal conversation. Cambridge, UK: Cambridge University Press.

Association of American Universities. (1998). Committee on graduate education: Report and recommendations. Washington, DC.

Austin, A. E. (2002). Preparing the next generation of faculty: Graduate school as socialization to the academic career. The Journal of Higher Education, 73(1), 94-122.

Bandura, A. (1989). Human agency in social cognitive theory. American Psychologist, 44(9), 1175-1184.

Bandura, A. (2000). Exercise of human agency through collective efficacy. Current Directions in Psychological Science. 75-78.

Bourdieu, P. (1986). The forms of capital. In J. G. Richardson (Ed.), Handbook of theory and research for the sociology of education (pp. 241-258). New York, NY: Greenwood Press.

Bourdieu, P. (1990). The logic of practice. Oxford, UK: Polity Press.

Bowen, W. G., \& Rudenstine, N. L. (1992). In pursuit of the PhD. Princeton, NJ: Princeton University Press.

Brandes, P., Dharwadkar, R., \& Wheatley, K. (2004). Social exchanges within organizations and work outcomes: The importance of local and global relationships. Group and Organization Management, 29(3), 276-301.

Campbell, C. M. (2012). Faculty agency: Organizational contexts that matter in faculty careers. Unpublished dissertation, University of Maryland, College Park.

Campbell, C. \& O'Meara, K. (2013, June 19). Faculty agency: Departmental contexts that matter in faculty careers. Research in Higher Education, 54(4) or 55(1), 49-74 in print.

Carnegie Foundation (2010). The Carnegie Classification of Institutions of Higher Education. Retrieved from http://classifications.carnegiefoundation.org/

Cech, E., Rubineau, B., Silby, S., \& Seron, C. (2011). Professional role confidence and gendered persistence in engineering. American Sociological Review 76(5), 641-666.

Christakis, N., \& Fowler, J. H. (2009). Connected: The surprising power of our social networks and how they shape our lives. New York: Little, Brown and Company.

Council of Graduate Schools (2010). PhD completion and attrition: Policies and practices to promote student success. Washington, DC.

Creswell, J. W. (2003) Research design. Qualitative, quantitative and mixed methods approaches (2nd ed.). Thousand Oaks, CA: Sage.

Creswell, J. W. (2007). Qualitative inquiry and research design: Choosing among five approaches (2nd ed.). Thousand Oaks, CA: Sage.

Creswell, J. W., \& Plano Clark, V. L. (2011). Designing and conducting mixed methods research (2nd ed.). Thousand Oaks, CA: Sage.

Elder, G. H., Jr. (1994). Time, human agency, and social change: Perspectives on the life course. Social Psychology Quarterly, 57(1), 4-15. 
Emirbayer, M., \& Mische, A. (1998). What is agency? American Journal of Sociology, 103(4), 962-1023.

Eteläpelto, A., Vahasantanen, K., Hokka, P., \& Paloniemi, S. (2013). What is agency? Conceptualizing professional agency at work. Educational Research Review, 10, 45-65.

Ferreira, M. M. (2003). Gender differences in graduate students' perspectives on the culture of science. Journal of Women and Minorities in Science and Engineering, 9(2), 119-135.

Frasier, H. (2013). An analysis of institutional characteristics that contribute to extended time to doctoral degree. Unpublished doctoral dissertation, University of Maryland, College Park.

Fries-Britt, S. L., Younger, T. K., \& Hall, W. D. (2010). Lessons from high achieving students of color in physics. New Directions for Institutional Research, 148, 75-83.

Fuhrmann, C. N., Halme, D. G., O'Sullivan, P. S., \& Lindstaedt, B. (2011). Improving graduate education to support a branching career pipeline: Recommendations based on a survey of doctoral students in the basic biomedical sciences. CBE-Life Science Education, 10(3), 239-249.

Ganz, M. (2010). Leading change: Leadership, organization and social movements. In N. Nohira \& R. Khurana, The handbook of leadership and practice (pp. 509-550). Danvers, MA: Harvard Business School Press.

Gardner, S. K. (2007). "I heard it through the grapevine": Doctoral student socialization in chemistry and history. Higher Education, 54(5), 723-740.

Gardner, S. K. (2008). Fitting the mold of graduate school: A qualitative study of socialization in doctoral education. Innovative Higher Education, 33(2), 125-138.

Gardner, S. K. (2009). Conceptualizing success in doctoral education: Perspectives of faculty in seven disciplines. The Review of Higher Education, 32(3), 383-406.

Gardner, S. K. (2010). Keeping up with the Joneses: Socialization and culture in doctoral education at one striving institution. The Journal of Higher Education, 81(6), 728-749.

Giddens, A. (1979). Central problems in social theory: Action, structure and contradiction in social analysis. London, UK: Macmillan.

Girves, J. E., \& Wemmerus, V. (1988). Developing models of graduate student degree progress. The Journal of Higher Education, 59(2), 163-189.

Glaser, B. G., \& Strauss, A. L. (1967). The discovery of grounded theory: Strategies for qualitative research. Piscataway, NJ: Aldine Transaction.

Golde, C. M. (1998). Beginning graduate school: explaining first year doctoral attrition. In M. S. Anderson (Ed.), The experience of being in graduate school: An exploration (pp. 55-64). San Francisco, CA: Jossey-Bass.

Golde, C. M. (2005). The role of the department and discipline in doctoral student attrition: Lessons from four departments. The Journal of Higher Education, 76(6), 669-700.

Golde, C. M., \& Dore, T. M. (2001). At cross purposes: What the experiences of doctoral students reveal about doctoral education. Philadelphia, PA: The Pew Charitable Trusts.

Gonzalez, J. C. (2006). Academic socialization experiences of Latina doctoral students: A qualitative understanding of support systems that aid and challenges that hinder the process. Journal of Hispanic Higher Education, 5(4), 347-365.

Haley, K. J., Jaeger, A. J., \& Levin, J. (in press). Not all going in the same direction: The effects of social identity on graduate student career choices. Journal of College Student Development.

Jairam, D., \& Kahl, D. H., Jr. (2012). Navigating the doctoral experience: The role of social support in successful degree completion. International Journal of Doctoral Studies, 7, 311-329.

Johnson, R. B., Onwuegbuzie, A. J., \& Turner, L. A. (2007). Toward a definition of mixed methods research. Journal of Mixed Methods Research, 1(2), 112-133. 
Kim, D., \& Otts, C. (2010). The effect of loans on time to doctorate degree: Differences by race/ethnicity, field of study, and institutional characteristics. The Journal of Higher Education, 81(1), 1-32.

Knox, S., \& Burkard, A. W. (2009). Qualitative research interviews. Psychotherapy Research, 19(4-5), $566-575$.

Kvale, S., \& Brinkman, S. (2009). InterViews: Learning the craft of qualitative research interviewing $\left(2^{\text {nd }}\right.$ ed.). Thousand Oaks, CA: Sage.

Laird, P. W. (2006). Pull: Networking and success since Benjamin Franklin. Cambridge, MA: Harvard University Press.

Lawrence, T. B. (2008). Power, institutions and organizations. In R. Greenwood, C. Oliver, K. Sahlin, \& R. Suddaby (Eds.), Sage handbook of organizational institutionalism (pp. 170-197). Thousand Oaks, CA: Sage.

Lawton, M. P. (1989). Environmental proactivity and affect in older people. In S. Spacapan \& S. Askamp (Eds.), The social psychology of aging (pp. 135-163). Newbury Park, CA: Sage.

Lerner, R., \& Busch-Rossnagel, N. (1981). Individuals as procedures of their development: Conceptual and empirical bases. In R. Lerner \& N. Busch-Rossnagel (Eds.), Individuals as producers of their development: A life-span perspective (pp. 1-36). New York, NY: Cambridge University Press.

Lincoln, Y. S., \& Guba, E. G. (2000). Paradigmatic controversies, contradictions, and emerging confluences. In N. K. Denzin \& Y. S. Lincoln (Eds.), Handbook of qualitative research (2nd ed., pp. 163188). Thousand Oaks, CA: Sage.

Lindholm, J. A. (2004). Pathways to the professoriate: The role of self, others and environment in shaping academic career aspirations. The Journal of Higher Education, 75(6), 603-635.

Lovitts, B. E. (2001). Leaving the ivory tower: The causes and consequences of departure from doctoral study. New York, NY: Rowman \& Littlefield.

Marshall, V. (2000). Agency, structure, and the life course in the era of reflexive modernization. Paper presented at the annual meeting of the American Sociological Association, Washington, DC.

Marshall, V. W. (2005). Agency, events, and structure at the end of the life course. In R. Levy, P. Ghisletta, J. Le Goff, D. Spini, \& E. Widmer (Eds.), Advances in Life Course Research: Vol. 10. Towards an interdisciplinary perspective on the life course (pp. 57-91). San Diego, CA: Elsevier.

Mason, M. A., Goulden, M., \& Frasch, K. (2009). Why graduate students reject the fast track. Academe, 95(1), 11-16.

Mertens, D. M. (2010). Transformative mixed methods research. Qualitative inquiry, 16(6), 469-474.

Merriam, S. B. (1998). Qualitative research and case study applications in education. San Francisco, CA: Jossey-Bass.

Millett, C. M., \& Nettles, M. T. (2006). Expanding and cultivating the Hispanic STEM doctoral workforce: Research in doctoral student experiences. Journal of Hispanic Higher Education, 5(3), 258-287.

Mwenda, M. N. (2010). Underrepresented minority students in STEM doctoral programs: The role of financial support and relationships with faculty and peers. Unpublished doctoral dissertation, University of Iowa. Retrieved from http://ir.uiowa.edu/etd/560

Nahapiet, J., \& Ghoshal, S. (1998). Social capital, intellectual capital, and the organizational advantage. Academy of Management Review, 23(2), 242-266.

National Science Foundation. (2004). Support of graduate students and postdoctoral researchers in the sciences and engineering: Impact of related policies \& practices. Washington, DC: National Science Foundation.

Nerad, M. (2009). Confronting common assumptions: Designing future-oriented doctoral education. In, R. G. Ehrenberg \& C. V. Kuh (Eds.), Doctoral education and the faculty of the future (pp. 80-89). Ithaca, NY: Cornell University Press. 
Neumann, A., \& Pereira, K. B. (2009). Becoming strategic: Recently tenured university professors as agents of scholarly learning. In A. Neumann, Professing to learn: Creating tenured lives and careers in the American research university. Baltimore, MD: The Johns Hopkins University Press.

Neumann, A., Terosky, A. L., \& Schell, J. (2006). Agents of learning: Strategies for assuming agency, for learning, in tenured faculty careers. In S. J. Bracken, J. K. Allen, \& D. R. Dean (Eds.), The balancing act: Gendered perspectives in faculty roles and work lives (pp. 91-120). Sterling, VA: Stylus Publishing.

O’Meara, K. (2013) Advancing Graduate Student Agency. Higher Education in Review, 10, 1-10.

O’Meara, K., Campbell, C., \& Terosky, A. (2011). Living agency in the academy: A conceptual framework for research and action. Paper presented at the Annual Conference of the Association for the Study of Higher Education, Charlotte, NC.

O’Meara, K., Knudsen, K., \& Jones, J. (2013). The role of emotional competencies in faculty-doctoral student relationships. The Review of Higher Education, 36(3), 315-348.

O'Meara, K., \& Niehaus, E. (2013, April 29). With a little help from my friends: The role of on and off campus relationships in faculty careers. Annual meeting of the American Educational Research Association, San Francisco, CA.

Opdenakker, R. (2006). Advantages and disadvantages of four interview techniques in qualitative research. Forum: Qualitative Social Research, 7(4). Retrieved from http://nbn-resolving.de/urn:nbn:de:0114fqs0604118

Paglis, L., Green, S. G., \& Bauret, T. N. (2006). Does advisor mentoring add value? A longitudinal study of mentoring and doctoral student outcomes. Research in Higher Education, 47(4), 451-476.

Powell, W. W., \& Colyvas, J. A. (2008). Microfoundations of institutional theory. In R. Greenwood, C. Oliver, K. Sahlin, \& R. Suddaby (Eds.), The sage handbook of organizational institutionalism (pp. 276-323). Thousand Oaks, CA: Sage.

Rhoades, G., Kiyama, J. M., McCormick, R., \& Quiroz, M. (2008). Local cosmopolitans and cosmopolitan locals: New models of professionals in the academy. The Review of Higher Education, 31(2), 209-235.

Rios, D. (2010). Minority status and privilege in the academy: The importance of race, gender, and socialization practices for undergraduates, graduate students and faculty. Unpublished dissertation, University of Michigan, Ann Arbor.

Rossman, G. B., \& Rallis, S. F. (2003). Learning in the field: An introduction to qualitative research. Thousand Oaks, CA: Sage.

Sen, A. K. (1985). Well-being, agency and freedom: The Dewey lectures 1984. Journal of Philosophy, $82(4), 169-221$.

Szelenyi, K. (2013). The meaning of money in the socialization of science and engineering doctoral students: Nurturing the next generation of academic capitalists? The Journal of Higher Education, 84(2), 266-294.

Weidman, J. C., Twale, D. J., \& Stein, E. L. (2001). Socialization of graduate and professional students in higher education - a perilous passage? San Francisco, CA: Jossey-Bass.

Welzel, C. \& Inglehart, R. (2010). Agency, values, and well-being: A human development model. Social Indicators Research, 97(1), 43-63. 

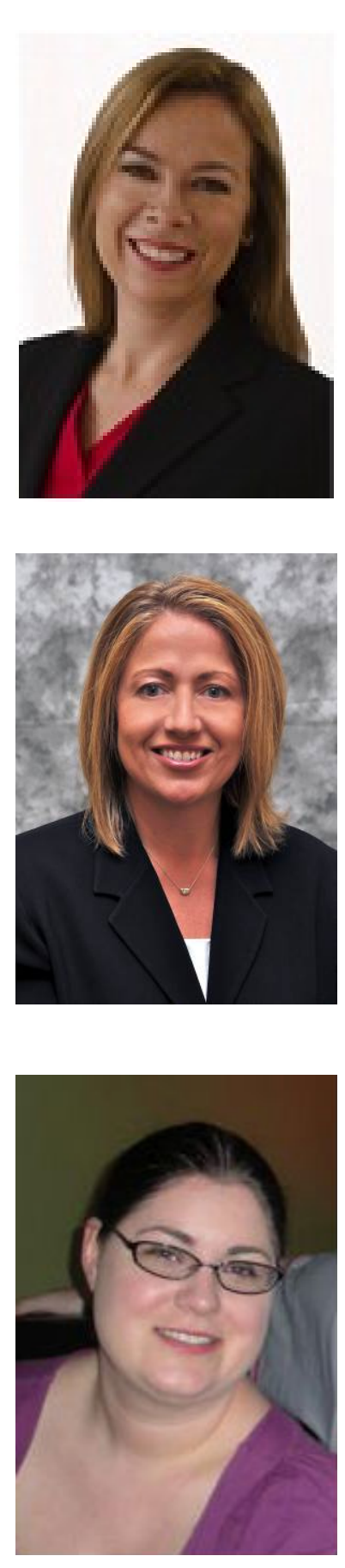

\section{Biographies}

Dr KerryAnn O'Meara is an Associate Professor of Higher Education in the College of Education and affiliate faculty in Women's Studies at the University of Maryland, College Park. She serves as the CoDirector and Co-PI of the University of Maryland National Science Foundation supported ADVANCE Program for Inclusive Excellence. Dr O'Meara's research examines organizational practices that support full participation, especially in areas of academic reward systems (b) faculty professional growth and careers and (c) faculty civic and community engagement.

Dr Audrey J. Jaeger is a Professor of Higher Education and Alumni Distinguished Graduate Professor in the Department of Leadership, Policy and Adult and Higher Education at North Carolina State University. She also directs the National Initiative for Leadership and Institutional Effectiveness (NILIE), an organization focusing on campus climate survey administration. Dr. Jaeger's research examines relationships and experiences among faculty and students that illuminate issues of transition, access, climate, agency, and civic and community engagement.

Jennifer Eliason is a doctoral student in the Higher Education specialization of the Counseling, Higher Education, and Special Education department at the University of Maryland, College Park. Her research agenda focuses on equity and diversity in the professoriate, graduate, and professional education. 


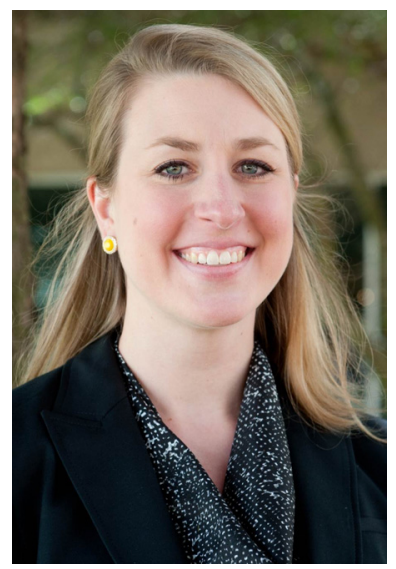

Ashley Grantham is currently pursuing a Ph.D. in Education Research \& Policy Studies at North Carolina State University. Her research interests focus on issues of organizational theory, policy, and teaching \& learning.

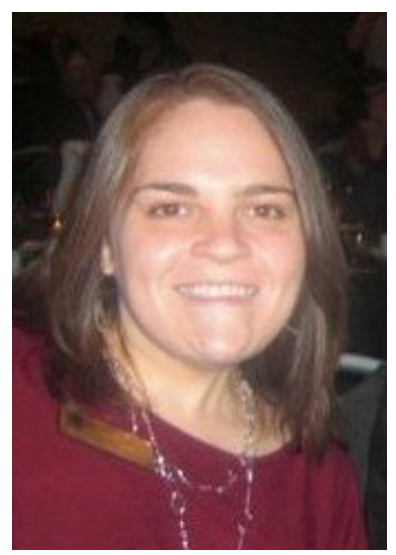

Kelly Cowdery is a doctoral student in the Higher Education specialization of the Counseling, Higher Education, and Special Education department at the University of Maryland, College Park. Her research is focused on faculty and the tenure system as well doctoral student education and career paths.

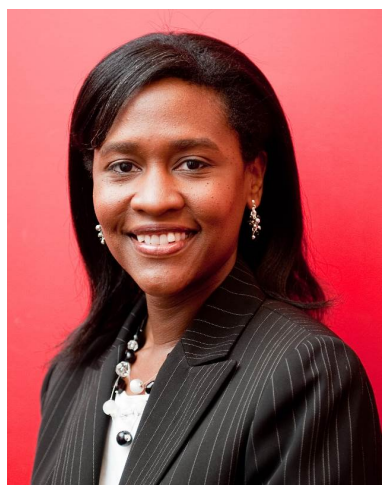

Allison Mitchall is a Ph.D. candidate in the Educational Research and Policy Studies at North Carolina State University. Her research interests include college access and retention issues for underrepresented students in higher education.

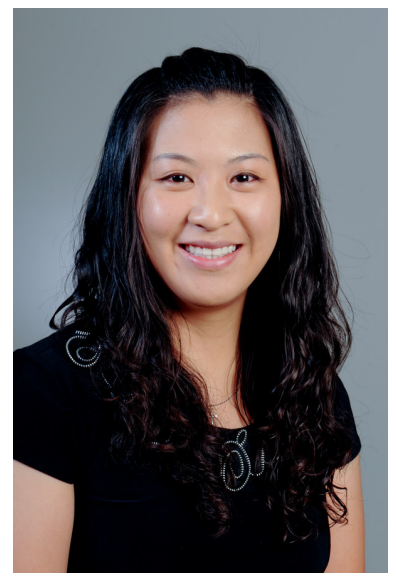

Jingjing Kate Zhang is an advanced doctoral candidate in the Educational Research \& Policy Studies: Higher Education Program at North Carolina State University. Her research explores factors that affect doctoral students' time to degree. 